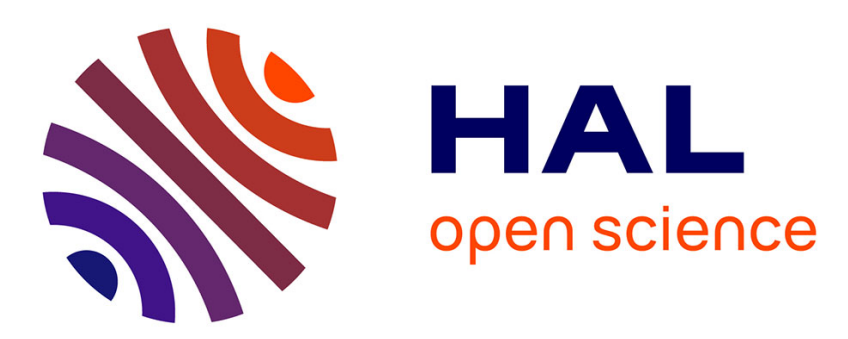

\title{
About the Double Degree Master's Programs between University Toulouse III-Paul Sabatier and Technical University of Liberec
}

Ileana Ober, Philippe Joly, Jaroslav Nosek

\section{- To cite this version:}

Ileana Ober, Philippe Joly, Jaroslav Nosek. About the Double Degree Master's Programs between University Toulouse III-Paul Sabatier and Technical University of Liberec. 2021 IEEE International Workshop of Electronics, Control, Measurement, Signals and their application to Mechatronics (ECMSM), Jun 2021, Liberec, France. pp.1-4, 10.1109/ECMSM51310.2021.9468839 . hal-03443921

\author{
HAL Id: hal-03443921 \\ https://hal.science/hal-03443921
}

Submitted on 23 Nov 2021

HAL is a multi-disciplinary open access archive for the deposit and dissemination of scientific research documents, whether they are published or not. The documents may come from teaching and research institutions in France or abroad, or from public or private research centers.
L'archive ouverte pluridisciplinaire HAL, est destinée au dépôt et à la diffusion de documents scientifiques de niveau recherche, publiés ou non, émanant des établissements d'enseignement et de recherche français ou étrangers, des laboratoires publics ou privés. 


\section{About the Double Degree Master's Programs between University Toulouse III-Paul Sabatier and Technical University of Liberec}

\author{
Ileana Ober \\ IRIT Toulouse, France \\ Philippe Joly \\ Université Toulouse III-Paul Sabatier, \\ IRIT Toulouse, France
}

\author{
Jaroslav Nosek \\ Technical University of Liberec, \\ Czech Republic \\ E-mail: jaroslav.nosek@tul.cz
}

\begin{abstract}
The paper focuses on the development of cooperation between University Toulouse III - Paul Sabatier (UPS, newly UT3) and Technical University of Liberec (TUL), culminating in the completion of the Double Degree Master's program "Engineering of Interactive Systems" (2009-2015) and "Computer Science for Aerospace" (2017 - 2021). The development of the International doctoral workshop $\operatorname{ECMS(M)}$ uses the patronage of IEEE.
\end{abstract}

Keywords - Engineering; Master's program; double degree; computer science; aerospace

\section{INTRODUCTION}

The collaboration of two major higher education institutions in Toulouse - Université Toulouse III-Paul Sabatier (UT3), Institut National Polytechnique (INP) - École nationale supérieure d'electrotechnique, d'electronics, d'informatique, d'hydraulique et des tecommunications ( ENSEEIHT) Toulouse, and the Technical University of Liberec (TUL), Faculty of Mechatronics, Informatics and Interdisciplinary Studies (FM) dates back to 1990 (UT3), or to 1995 (INP), respectively.

The joint activities are based on the scientific and educational experience of the UT3 and INP to develop cooperation in educational, scientific, and cultural fields. Josiane Poque and Michel Courdesses (UT3), later Bertrand Nogarede, Jean-Francois Rouchon, and Francois Pigache (INP) were the major contributors to the collaboration.

Over the years, several projects have been prepared together with UT3: Tempus (1990-92), COST (2003-2005), Barrande (2006), Surveyor (2006-08), REGPOT1 (2009).

Many UT3 employees, such as George Zissis, and TUL, such as Aleš Richter, were involved in these projects.

The implementation of the Socrates, Erasmus LLP, and Erasmus + projects has been a significant help, which has enabled staff and Ph.D. students from UT3, INP, and TUL universities.

Copyright: 978-1-5386-1757-1/21/\$31.00 (C2021 European Union
There were lectures of French professors at TUL (Michel Courdesses, Yannick Deville, Philippe Joly, Pascal Sainrat, Jean-Francois Rouchon, Bertrand Nogarede, Francois Pigache), and Czech professors at INP ENSEEIHT (Jaroslav Nosek, Lidmila Burianova); a number of TUL experts visited laboratories of the UT3 and INP [1].

Since 1993, we organize the International doctoral workshops on Electronic, Control, Measurement, and Systems (ECMS) biannually in Liberec or Toulouse. One of the actual results was incorporating ECMS into regular Doctoral Schools Toulouse (EDSYS, GEET) by Michel Courdesses.

In 1995, the Faculty of Mechatronics, Informatics, and Interdisciplinary Studies started at TUL. The UPS / UT3 participated in the proposal to establish a new faculty at TUL. The latest Faculty of Mechatronics, Informatics, and Interdisciplinary Studies focuses on the three main profiles: control of mechatronic systems, information technology, and nanotechnology.

In 2009, the 9th International Workshop on Electronics, Control, Modeling, Measurement, and Signals was firstly carried out at Mondragon Unibertsitatea (Spain) by JuanCarlos Mugarza.

Since 2011, the ECMS supported by IEEE (IEEE ECMS 2011 in Liberec by Zdeněk Plíva, Jaroslav Nosek, and Philippe Joly).

In 2013, the ECMS was organized at INP-ENSEEIHT Toulouse (by Francois Pigache), such as the International Workshop on Electronic Control, Measurement, Signals and their Application to Mechatronics (ECMSM 2013).

Another ECMSM 2015 workshop was prepared at TUL by Zdeněk Plíva and in 2017 in San Sebastian by Juan Carlos Mugarza with their Mondragon colleagues.

All contributions selected for this event were published by the IEEExplore in the IEEE Computer Science Digital Library and referenced in the Web of Science and Scopus.

The original doctoral workshop ECMSM has evolved into a regular international conference sponsored by IEEE.

Joint activities of UT3 and TUL were supported by representatives of these universities - by President of the UT3 Jean-Claude Martin and by Rector of the TUL Zdenek Kovar.

In 2018, the President of UPS/UT3 Jean-Pierre Vinel and and the Rector of TUL Zdeněk Kůs signed the new „Accord de cooperation interuniversitaire" [2] and "Accord d'appplication d'un programme d'étude conjoint „, Computer 
Science for Aerospace - Information Technology" entre l'UPS Toulouse et TU Liberec" [3].

These documents set out the conditions for a Double Degree Master's Program named "Computer Science for Aerospace - IT." The program guarantee by Ileana Ober (IRIT Toulouse). The new program builds on a previous Double Degree Master's Program, "Engineering of Interactive Systems," guaranteed by Philippe Joly (IRIT Toulouse, UPS/UT3).

In 2021, the "Memorandum of Understanding" sign by President Jean-Marc Broto and Rector Miroslav Brzezina opens up new possibilities, especially in doctoral programs GEETS where Georges Zissis is active [8].

\section{CHARACTERISTICS OF THE IEEE ECMSM}

The number of active participants in the ECMSM conferences and the quality of the contributions has increased, as evidenced by the following data from IEEE ECMSM 2017, organized by Mondragon Unibertsitatea (Juan Carlos Mugarza as the Chair of the conference, see a web http://ecmsm2017.mondragon.edu/en .

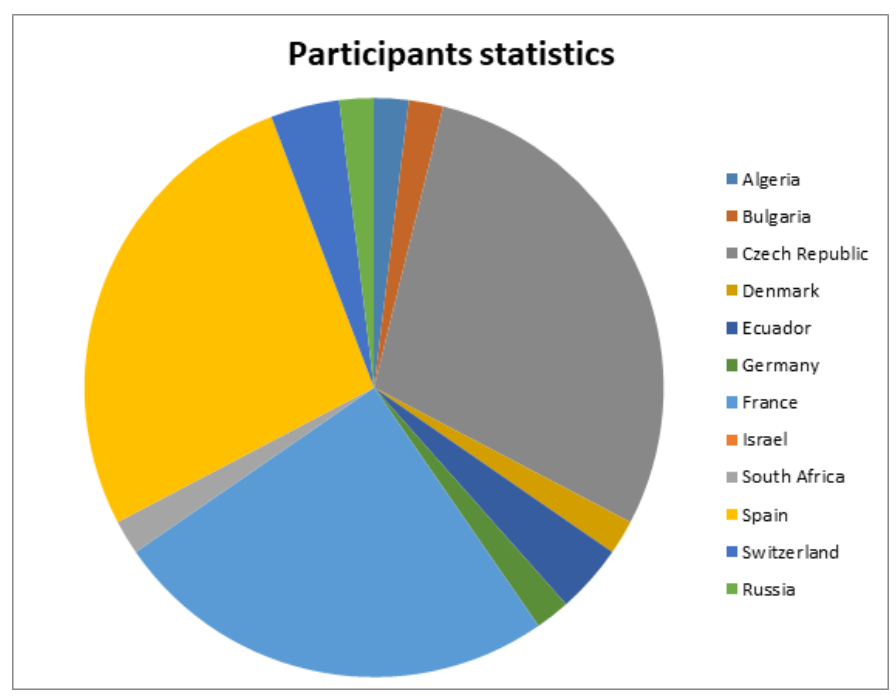

Fig. 1: The participant's statistics of the IEEE ECMSM 2017, San Sebastian, Spain [4]

The conference participants were from 12 countries, most of them from Spain, France, and the Czech Republic.

$\begin{array}{ll}\text { The Number of contributions to the IEEE ECMSM } 2017 \\ \begin{array}{l}\text { San Sebastian: } \\ \text { Received abstracts: }\end{array} & 85 \\ \text { Received paper for reviewing: } & 65(76,5 \%) \\ \begin{array}{l}\text { First reviewing process results: } \\ \text { Accepted papers: }\end{array} & 12(18,5 \%)^{(1)} \\ \text { Probably accepted, with minor changes: } & 23(35,4 \%) \\ \text { Possible acceptation, with major changes: } & 22(33,8 \%) \\ \text { Rejected: } & 8(12,3 \%)\end{array}$

\section{San Sebastian:}

Received paper for reviewing:

First reviewing process results:

Accepted papers:

Possible acceptation, with major changes:

Final reviewing process results:
Accepted papers:

$57(87,7 \%)^{(1)}$

Rejected:

Finally accepted received:

Published at the IEEE proceedings:

54

(1) of the 65 accepted contributions,

(2) of the 84 abstract submissions.

\section{DOUBLE DEGREE MASTER'S PROGRAMS BETWEEN UNIVERSITY TOULOUSE III-PAUL SABATIER AND TECHNICAL UNIVERSITY OF LIBEREC}

A. Engineering of Interactive Systems (EIS)

The first of the joint programs - "Engineering of Interactive Systems" - was designed as a pilot project in 2009 and supported by the Czech Ministry of Education, Youth and Sports (MSMT) and by the Ministère de l'Eseignement supérieur, de la Recherche et de l'Innovations in Paris on the French side. Philippe Joly and Jaroslav Nosek prepared the project.

\section{The objective of the joint study program}

The objective of the postgraduate Master's program "Engineering of Interactive Systems," which is in English, is to acquire theoretical knowledge and practical skills in the field of interactive intelligent systems.

The graduate's competencies require the cooperation of two scientific and technical categories: automatic systems and informatics. For this reason, the proposed discipline is multidisciplinary, consisting of three components: artificial intelligence, human-machine interaction, and robotics / production.

The field profile will enable the engineer to work in the technology sector, which is presently the penetration of informatics (including industrial informatics) and automation.

The output of the new study program is therefore strongly focused on new industrial technologies.

The graduate will find work in the European labor market. We assume that some graduates will continue their doctoral degree programs at TUL in Liberec, or Université Toulouse III-Paul Sabatier, in doctoral schools GEETS or MITT.

The first students enrolled in the EIS program in the academic year 2009/2010:

TABLE I. STUDENTS IN THE STUDY PROGRAM EIS [5]

\begin{tabular}{|c|c|c|c|}
\hline $\begin{array}{l}\text { Academic } \\
\text { Year }\end{array}$ & Matriculation & $\begin{array}{c}\text { Graduation at } \\
\text { UPS }\end{array}$ & $\begin{array}{c}\text { Graduation at } \\
\text { TUL }\end{array}$ \\
\hline $2009 / 2010$ & $\begin{array}{c}4 \text { (three } \mathrm{CZ} \text {, one } \\
\text { F) }\end{array}$ & $\begin{array}{c}3 \text { (two CZ, one } \\
\text { F) } \\
\text { Sept. } 2011 \\
\end{array}$ & 3 (three CZ) \\
\hline $2010 / 2011$ & $\begin{array}{c}6 \text { (three } \mathrm{CZ} \text {, } \\
\text { three F) }\end{array}$ & $\begin{array}{c}2 \mathrm{~F} \text { (one F did } \\
\text { not finish) } \\
\text { Sept.2012 }\end{array}$ & $\begin{array}{c}\text { 3three } \\
\text { June } 2012\end{array}$ \\
\hline $2011 / 2012$ & $\begin{array}{c}5 \text { (three CZ, two } \\
\text { international } \\
\text { students) }\end{array}$ & $\begin{array}{c}\text { One CZ did not } \\
\text { finish at UPS, } \\
\text { Defense of one } \\
\mathrm{CZ} \text { and one one } \\
\text { international } \\
\text { student in Sept. } \\
2013\end{array}$ & $\begin{array}{c}\text { One } \\
\text { international } \\
\text { student in } \\
\text { February or } \\
\text { June } 2014, \\
\text { One CZ in } \\
\text { February } 2014, \\
\text { two CZ in } 2013\end{array}$ \\
\hline
\end{tabular}

The accreditation of the study program EIS ended in 2017. 
Due to the continued penetration of Information Technology (IT) into the control of highly developed systems, a new project, "Computer Science for Aerospace" (CSA), was created on the French side, guaranteed by UT3 and IRIT Toulouse, and by Ileana Ober and Philippe Joly.

The CSA study program at UT3 is in English since 2015. Between 2016 and 2017, the new Master's degree program CSA and IT was prepared and accredited on the French side.

An important part was comparing the 1st year study (M1) subjects CSA and IT programs at TUL. Based on the cooperation agreements [2], [3], the CSA-IT program was approved and implemented in the following sequence of semesters:

TABLE II. PATERN OF THE YEARS AND SEMESTERS FOR THE CSAIT PROGRAM

\begin{tabular}{|c|c|}
\hline $\begin{array}{c}\text { M1/S1 (12 weeks in Toulose / } \\
\mathbf{1 4} \text { weeks in Liberec) }\end{array}$ & $\begin{array}{c}\text { M1/S2 (12 weeks in Toulouse / } \\
\mathbf{1 4} \text { weeks in Liberec) }\end{array}$ \\
\hline CSA Toulouse (in English) & CSA Toulouse (in English) \\
\hline IT Liberec (in English) & IT Liberec (in English) \\
\hline M2/S3 (12 weeks in Toulouse / & M2/S4 (5 months in Toulouse, \\
$\mathbf{1 4}$ weeks in Liberec) & $\mathbf{1 0}$ weeks in Liberec \\
\hline CSA Toulouse (in English) & CSA Toulouse (in English) \\
\hline IT Liberec (in English) & IT Liberec (in English) \\
\hline Erasmus+ study stay & Erasmus+ study stay \\
\hline
\end{tabular}

Kind of study of the postgraduate Master's program CSA-IT

The IT Master's program at TUL offers nine compulsory subjects in the first year (M1), seven compulsory electives subjects, and one semestral project.

In the M2, there are four compulsory subjects and 15 compulsory electives subjects, and a Diploma Thesis. Of these 15 courses, students choose to reach the minimum number of credits.

\section{Profile of the program}

Both universities guarantee the dual degree program CSA-IT in English. At UPS Toulouse, a Czech student will study the 2nd year (M2) in the CSA program; at the end of his study (September 2022), the student defends his "Master Thesis" and then receives a Master's degree in CSA.

Then the student will apply for recognition of the study results obtained at the foreign university by the Technical University of Liberec. Based on the recognition and acquisition of 60 ETCS credits for the 2nd year, the student can apply for the closest term of the "State Final Examination" and defend his "Diploma Thesis" at TUL - Faculty of Mechatronics, Informatics and Interdisciplinary Studies (not earlier than in February 2023). Then the student is awarded the "Engineer" diploma.

Form of study: full-time

Financial support: Erasmus + program [6].

We apply a similar scheme to applicants who have completed the M1 CSA in Toulouse. The student enters the M2 year at TUL, where he receives the assignment of his Diploma Thesis. The study typically ends in June with the State Final Examination. The graduate obtains the title "Inženýr." He then applies to UT3 to recognize his secondyear studies in Liberec and defends his Master's Thesis in Toulouse.
Successful graduates of this Master's program will receive the title of "Master" and "Inženýr" (Ingénieur). These titles recognize both countries and the EU.

Both projects, "Engineering of Interactive Systems" and "Computer Science for Aerospace," have similar objectives.

\section{Ability of graduate}

A graduate of the study program CSA-IT can design, implement, and operate complex autonomous systems equipped with decision-making, action and perception functions, and techniques that depend on the environment and the human factor.

The graduate of the study program has the capabilities in particular:

-To transmit and develop new technologies,

-To take responsibility for managing and administering such systems,

-To promote economic development on a regional and European scale, particularly by contributing to the creation and the development of industrial and technologically advanced companies.

\section{Essential prerequisites}

The essential prerequisites for creating a joint study program are as follows:

a) The existence of an inter-university cooperation agreement

b) The similarity of relevant Master's programs at both universities

c) The activity and willingness of the responsible staff of both universities to create a joint program

d) Program proposal and its personnel, financial and technical support

e) Accreditation of the proposed program in France and in Czech Republic

(f) Mutual recognition of parts of study undertaken abroad and compliance with the internal regulations of both universities

g) Financial support for project implementation (MESRI Paris, MSMT Prague)

h) Financial support of students by the project Erasmus+ for one year

i) Preparation of the "Master Study Program Guide."

j) Implementation of the admission procedure for the study program and fulfillment of all legal conditions for admission, course of study, and completion of diplomas at both universities.

TABLE III. STUDENTS IN THE STUDY PROGRAM CSA

\begin{tabular}{|c|c|c|c|}
\hline $\begin{array}{c}\text { Academic } \\
\text { Year }\end{array}$ & Matriculation & $\begin{array}{c}\text { Graduation at } \\
\text { UPS/UT3 }\end{array}$ & $\begin{array}{c}\text { Graduation at } \\
\text { TUL }\end{array}$ \\
\hline $2018 / 2019$ & 26 & 12 & $\begin{array}{c}\text { No } \\
\text { accreditation }\end{array}$ \\
\hline $2019 / 2020$ & 21 & 12 & $\begin{array}{c}\text { No } \\
\text { accreditation }\end{array}$ \\
\hline $2020 / 2021$ & 28 & 11 & $\begin{array}{c}\text { No } \\
\text { accreditation }\end{array}$ \\
\hline
\end{tabular}

Although we point out the complexity of the implementation of the study program EIS, resp. CSA-IT, the advantage is the very good placement of graduates of these programs in major international companies. An example is the extraordinary admission of a Czech EIS graduate to the development department of Freescale Toulouse.

Completion of the program with a double diploma gives the possibility of involving graduates in the EU labor market, 
or continuing their doctoral studies at UT3, at TUL (Technical Cybernetics program), or at an institute of the ASCR.

The Faculty of Mechatronics, Informatics and Interdisciplinary Studies has experience with a similar program, which is carried out under the name "Mechatronics" in cooperation with the University of Applied Science Zittau (Germany). Graduates of this double-diploma program have very good placements in industrial companies in Germany or the Czech Republic. An example is Škoda Auto.

A similar study under a double diploma is successfully implemented in cooperation with the high-quality Novosibirsk State Technical University, Faculty of Automation and Computer Engineering. The program builds on the experience from the creation and implementation of the "double degree" master's degree program "Automation / Mechatronics," which took place in 2012-14 within the Tempus MPAM project (517138-Tempus-1-2011-1-CZ -Tempus-JPCR EU -PC) [7].

Table III presents the numbers of CSA students in the years following the end of accreditation of a successful EIS program. There was a shortcoming on TUL-FM, which consisted of the late accreditation of the IT master's program in English. For this reason, the numbers of TUL students are not given in Table III.

However, the program has been accredited and is still being implemented on the French side. The possible participation of students in the IT program was resolved by a special agreement between UT3 and TUL [2], [3]. The contract was conditional on a detailed comparison of the content of CSA and IT subjects in the 1st year of master's studies (recognition of M1) and the approval of all responsible bodies at both universities.

Cooperation with such a high-quality university as UT3 also has an impact on doctoral studies. With the support of the Erasmus + program and especially with the support of Michel Courdesses and Vivianne Cadenat, 3 internships of TUL doctoral students took place in LAAS CNRS Toulouse, Laboratoire d'Analyse et d'Architecture de Systèmes, RAP group (Robotique, Action et Perception) who are interested in the functional search of various robotic systems.

Another important partner is AIME - Atelier interuniversitaire de micro-nano électronique in Toulouse. Every year, internships of employees and doctoral students of the Institute of Information Technology and Electronics occur at this workplace. Thus, the scientific basis in microelectronics is developing, especially the design of built-in diagnostics into integrated circuits, optimization of test samples and comparison of hardware overhead of various diagnostic approaches. Zdenek Pliva cooperates very well here.

The management of two TUL doctoral students in the "en cotutelle" regime is also a remarkable success. The partner workplace is the LAPLACE laboratory (formerly called CPAT). Doctoral student Jan Koprnický participated in the solution of the project COST Action no. 529: "Efficient Lighting for the 21st Century", https://cordis.europa.eu/project/id/2327, the trainer was George Zissis.
The second doctoral student in the LAPLACE laboratory was a doctoral student Leoš Kukačka.

Led by George Zissis practical on the issue of "Power Quality in DC Grids - Application to Lighting Systems."

A new contract for internship opportunities for doctoral students in the Environmental Engineering program was signed in 2021 [8]. In addition to the GEETS doctoral school (G. Zissis and LAPLACE laboratory), other doctoral schools (SEVAB) and laboratories in Toulouse are contacted.

\section{IV.CONCLUSION}

Collaboration between Université Toulouse III - Paul Sabatier, Toulouse, Institut National Polytechnique - École nationale supérieure d'électrotechnique, d'électronique, d'informatique, d'hydraulique et des télécommunications Toulouse, Unibersitatea Mondragon, and Technical University of Liberec has achieved significant International doctoral workshops ECMSM, which IEEE guarantees.

As a very considerable achievement, we consider the realization of the Double Degree Master's Program called "Computer Science for Aerospace - Information Technology" between Université Toulouse III-Paul Sabatier, Toulouse and Technical University of Liberec.

\section{ACKNOWLEDGEMENT}

The authors thank the TUL, Department of Mechatronics, and Computer Engineering for their support.

\section{REFERENCES}

[1] J.Poque, L.Burianova, J.Nosek, "About cooperation between Paul Sabatier University Toulouse, National Polytechnic Institute Toulouse and Technical University of Liberec", Proc. ECMSM 2013, Toulouse, pp. 1-4, ISBN: 978-1-4673-6297-9.

DOI: 10.1109/ECMSM.2013.6648961

[2] "Accord de cooperation interuniversitaire entre UPS et TU Liberec", Toulouse, Liberec, 2017.

[3] "Accord d'application d'un programme d'etude conjoint "Computer Science for Aerospace" - "Information Technology" entre UPS et TUL", Toulouse, Liberec, 2017.

[4] J-C.Mugarza, The ECMSM 2017 staistics,. Mondragon, 2017.

[5] Joint Master's programme "Engineering of Interactive Systems" - study results. UPS Toulouse and TU Liberec, 2014.

[6] Erasmus+ Inter-institutional agreement 2014-2021 between UPS Toulouse and Technical University of Liberec, Liberec, 2014.

[7] Tempus MPAM (517138-Tempus-1-2011-1-CZ-Tempus-JPCR EUPC), 2012-2014.

[8] "Memorandum of Understanding" between UT3 and TUL, February 2021 . 